\title{
Development of marine and coastal pollution training curriculum for master's study level
}

\author{
K. Luht ${ }^{1,2}$, T. Kull ${ }^{1} \&$ A. Tammepuu ${ }^{1,3}$ \\ ${ }^{I}$ Estonian Academy of Security Sciences, Estonia \\ ${ }^{2}$ Tallinn University of Technology, Estonia \\ ${ }^{3}$ Estonian University of Life Sciences, Estonia
}

\begin{abstract}
This paper discusses the development of a marine and coastal pollution training curriculum and learning materials for enhanced management level competence. Currently, the existing training programmes in this field embrace mostly specific subjects and target groups. For instance, short courses for rescue services, police and border guards as well as volunteers exist in the Baltic Sea region. Simultaneously, background studies brought out, that no comprehensive high level training curriculum covering this field exists in the countries of the region. The results of the analyses of pollution case reports demonstrated an urgent need for an extensive course programme, enabling the specialisation of marine and coastal pollution prevention, control and response. The curriculum was worked out on the basis of a Master's Programme of the Estonian Academy of Security Sciences, being available also for students of other countries in the region. The study and development work were carried out within the framework of the Interreg IV A EnSaCo "Environment and Safety Management Cooperation on Shoreline Oil Spill Response". This curriculum is designed to utilise the unified competence of several research and development institutions as well as civil services and foreign experts. The essential endeavours of the developed course are a proportional coverage of all the steps of pollution management, and a balanced approach to coastal and marine pollution subjects.

Keywords: education and training, pollution prevention, oil spills, offshore pollution, disaster management.
\end{abstract}




\section{Introduction}

Major oil and chemical spills, contrary to minor ones, are not very usual but the results of these accidents are extremely terrible. Approximately 42 accidents involving oil spills of over 7 tonnes have taken place from 1970-2011, the main oil spills occurred in western and Mediterranean Europe (13 of 20 major oil spills) [1].

Europe is the world's largest market in crude oil imports (about 30\% of the world total), and nearly $90 \%$ of oil and refined products are transported to and from Europe by sea [2]. Among the European seas the Baltic Sea is especially sensitive to pollution. Since 2005 the Baltic Sea area (Denmark, Estonia, Finland, Germany, Latvia, Lithuania, Poland and Sweden) has been designated as a Particularly Sensitive Sea Area (PSSA). This means an area that needs special protection through action by IMO because of its significance for recognized ecological or socio-economic or scientific reasons and which may be vulnerable to damage by international maritime activities (PSSA IMO) [3].

The cooperation between the Baltic Sea area countries is coordinated by the Baltic Marine Environment Protection Commission (Helsinki Commission further also: HELCOM), whose aim is the protection of the Baltic Sea marine environment from all kinds of pollution [4]. The Interreg IV A EnSaCo "Environment and Safety Management Cooperation on Shoreline Oil Spill Response" [5] is one of the numerous projects, which supports the HELCOM directions. The project is conducted to improve the preparedness of Estonia, Finland, Sweden and Russia [6]. The main objective of the project is to raise the level of expertise and to identify cross-border shoreline response cooperation. Therefore, at the culmination of the project, the authorities of the partner countries will be on a new level of competence and will meet the requirements of the Baltic Sea Action Plan [6].

Although most of the Baltic Sea countries have different kinds of oil spill training programs, a high-level and comprehensive curriculum, enabling the specialisation for accidental marine and coastal oil pollution is absent. Therefore the compilation of such a curriculum on a master's study level, being initially applied at Estonian Academy of Security Sciences, was posed as one of the goals of EnSaCo Oil Spill project. The objectives of the curriculum development are brought out as follows. Firstly, to provide an extensive background knowledge in the field of pollution. Secondly, proportional coverage of all steps of accidental pollution management, including: prevention, mitigation, emergency planning and recovery as well as control and investigation. Thirdly, a balanced approach to marine and coastal pollution and fourthly, international applicability and cooperation. Project activities will be carried out by Estonian, Finnish, Swedish and Russian specialists [5].

\section{Oil spills and accidental pollution globally and in the EU}

During the last decades large oil spill accidents have happened worldwide. Since the 1980 s spills of 700 metric tons or more average at four a year (before it was 
nine a year) [7]. The most typical causes of accidents include equipment failure, personnel mistakes, and extreme natural impacts (seismic activity, ice fields, hurricanes, and so on) [8]. Potential sources of spillage vary widely in the "life cycle" of petroleum - during exploration and production, transport, refining, storage or usage or waste disposal [9].

The largest oil spills in history are from platforms, pipelines and vessels; in the area of Baltic Sea the main problem is transport by vessels. Major worldwide oil spills from ships with a spill size of more than 100,000 tonnes are the Atlantic Empress (1979), ABT Summer (1991), Castillo de Beliver (1983), Amoco Cadiz (1978), Haven (1991), Odyssey (1988), Torrey Canyon (1967), Sea Star (1972), Irenes Serenade (1980), Urduiola (1976) [10], five of them took place in Europe.

The problem of accidental pollution in Europe has been the focus of public attention since the emergency with the tanker Torrey Canyon in the English Channel in 1967, where 95,000 tons of oil caused heavy pollution. Later remarkable accidents were in 1978 the Amoco Cadiz, with 220,000 tons of oil spilled; in 1989 the Exxon Valdes spilled 40,000 tons, and in 1993 the Braer with 85,000 tons of oil spilled [8].

The following two accidents had the greatest impact for the development of EU regulations in the fields of marine traffic and accidental pollution. Firstly, the Erica in 1999, where 15 organisations were engaged and individuals, the spill killed between 60,000-300,000 birds [10]. Secondly, the Prestige in 2002, where a fleet of 14 European ORV (oil recovery vessels), aerial assets of 25 helicopters and aircrafts, and in some cases up to 12.000 people, worked simultaneously on the beaches [11]. For example, the regulation (EC) No 417/2002 of the European Parliament and the Council enacts that the final date by which all single hull oil tankers are to be removed from use, is the year 2015 [12].

Accidental marine pollution has a great impact on economic, ecological and security situations confirming the need for spill prevention mechanisms and emergency response systems (inc. operational forecasting, risk and damage assessment, restoration measures, and monitoring activities) [13]. Flora and fauna are generally the main damageable ecosystem constituents by the spills [14]. Although oil spills get the most of public attention they only account for $12 \%$ of all chemical spills [15].

\section{Baltic sea region}

\subsection{General overview}

The Baltic Sea is one of the largest bodies of brackish water in the world; it has unique and fragile ecosystems with naturally low numbers of species. It is an unusually land-locked sea and therefore the water exchange is limited. Highly sensitive to all kinds of pollution and surrounded by many large cities and regions and at the same time one of the busiest shipping lanes in the world $[16,17]$. Fauna in the Baltic Sea is divided into fresh water, brackish and marine fauna; all of them are very sensitive and have their own living space $[17,18]$. 
The Baltic Sea Region, with eight EU member States and Russia and nearly 100 million people, is a highly heterogeneous area in economic, environmental and cultural terms, yet the countries concerned share many common resources and demonstrate considerable interdependence [19]. The total Baltic Sea catchment area comprises $1,720,270 \mathrm{~km}^{2}$ [20]. The average total number of ships crossing the Baltic Sea is 400000 ships per year; tankers comprise approximately 16.5 percent of the total $[21,22]$.

\subsection{Maritime traffic accidents in Baltic sea region}

According to the HELCOM Automatic Identification System (AIS) for monitoring maritime traffic, there are about 2,000 ships in the Baltic marine area at any given moment (accounting for $15 \%$ of the world's cargo transportation and this is predicted to increase by over $100 \%$ in the Baltic Sea, especially oil tankers [19] and each month around 3,500-5,000 ships ply the waters of the Baltic Sea [23]. There have been a lot of accidents, mostly without any pollution but this doesn't mean that it isn't possible. The main risk of Baltic Sea accidental marine and costal pollution is spillage from tank vessels.

1068 accidents took place in the Baltic Sea during the period 2001-2010, 42\% of them were grounding, $32 \%$ collisions, $8 \%$ fires and $12 \%$ other types [22].

The geographical scope of the EnSaCo Oil Spill project is directed to the Gulf of Finland but can be applied to the areas of the Baltic Sea as well [5]. Grounding is the dominant type of accident in The Gulf of Finland, most of which happened in coastal areas or in ports. Most of the collisions occurred in February or March in ice channels. The route between Helsinki and Tallinn is one of the main marine traffic risk assessment focus objects in this area [24]. The consequences of an oil spill depend upon different variables such as the behaviour of the oil after the spill, the sea level, wind direction and wind speed [25].

\subsection{Pollution management and control in Baltic sea region}

The Baltic Sea has gone through a major change from an oligotrophic clearwater to a highly eutrophic marine environment [26]. Nutrients originate from different sources e.g. industry, agriculture and forestry, atmospheric deposition, transportation including shipping etc. [27].

The Baltic Sea countries are working together under the HELCOM (The Helsinki Commission) Baltic Sea Action Plan, which has four major goals: eutrophication, hazardous substances, maritime activities and biodiversity [16].

Under the HELCOM convention each contracting party shall draw up a national contingency plan and in co-operation with other Contracting Parties, as appropriate, bilateral or multilateral plans for a joint response to pollution incidents. The Baltic Sea Action Plan involves all the Baltic coastal states, including Russia as the only non-EU member, as well as other countries in the Baltic catchment area. 


\subsection{Pollution response arrangements in the EnSaCo countries}

The comparison of the pollution response arrangements of EnSaCo participant countries on the basis of The International Tanker Owners Pollution Federation (ITOPF) materials [28] demonstrated remarkable differences in the distribution of responsibility. For instance, in Finland the overall responsibility for response arrangements lays with the Ministry of Environment, in Sweden the Ministry of Defence and in Estonia the Ministry of the Interior. The Russian Federation has two responsible ministries: the Ministry of Transport is responsible for responding to marine pollution incidents; simultaneously the Russian Ministry of Civil Defence, Emergencies and Disaster Response is responsible for the coordination of different services, which are involved in combating oil spills.

The technologies for combating oil spills are more or less similar in all the EnSaCo participant countries and in the whole Baltic Sea Region, which simplifies cooperation in practical actions and training. There are around 70 dedicated response vessels (vessels with oil response equipment which can be used for international assistance) available in the region, many of the vessels have a substantial towing capacity and additional vessels are available for accidents in ports and coastal waters [22]. These vessels belong to nine countries and one organisation - The European Maritime Safety Agency (EMSA). This means that people have to know each other and have to understand the main risks in the area.

\section{Curriculum development and application}

\subsection{Current state of oil spill training in EnSaCo countries}

Today none of the partner states of EnSaCo provides a higher education curriculum that would support oil spill study. Marine and coastal accidental oil pollution training has been either a small part of some curriculum or a subject in the institutions of higher education, or special short refresher or qualification courses in the recent practice of these countries. The subsequently observed cases are only selected examples for characterizing the current state in these countries.

In Finland, at the Emergency Services College, oil spill training is a part of the environmental safety course, taught together with other types of environmental accidents and response efforts [29]. Another example, from Finland are short-time courses, lasting up to one day, for different target groups of volunteers, organized by World Wildlife Fund (WWF) [30]. The Kymenlaakso University of Applied Sciences has worked out a training curriculum for coastal pollution, consisting of four levels and targeted to oil spill response trainers from rescue services and other institutions [31].

In Sweden the Swedish Rescue Board has arranged courses, consisting of four steps, which are addressed to different target groups, including for instance rescue, coastal guard, environmental and health protection, municipal officials, volunteers, etc. [32]. Another example of Swedish oil spill response training is a 
2-day course at Kalmar Maritime Academy: Marine Environment Protection Program (MEPP) [33]. The first day involves lectures and discussion and the second day is practical exercise.

In Russia the Makarov Training Centre [34] conducts oil pollution prevention and response training for a wide range of specialists. The training is divided between three levels, depending on the position of a specialist, beginning from practitioners on the scene of the accident to top management The first level involves the immediate responders to oil spills and pollution, the second level the direct leadership staff and the third level is directed to higher management personnel.

In Estonia, at the Academy of Security Sciences, the elements of oil spill response are taught in the frames of different subjects. Volunteer training is carried out in the form of short courses, organized by the Estonian Nature Fund [35]. The training involves mostly coastal pollution.

\subsection{Methodological approach}

The essential principle of the curriculum development was based on the cyclic character of the oil spill management process. While working out the curriculum and its application and implementation mechanisms we used the principles of the following models. Firstly, the four-step circle of emergency management (Figure 1), as recommended by the EU Civil Protection [36] and Schwab et al. [37]. Secondly, the well-known Plan-Do-Check-Act (PDCA) model (Figure 2), widely used in several management processes, standardised by ISO [38, 39] and also being applied by some authors in the field of emergency response [40]. Additionally we observed similar cyclic models; presented by Smith [41] as well as the special accidental spill response cycle diagram, developed by Kirby and Law [42]. The emergency management cyclic model(s) served as an example mostly for the curriculum design and the PDCA model for compiling the application mechanism.

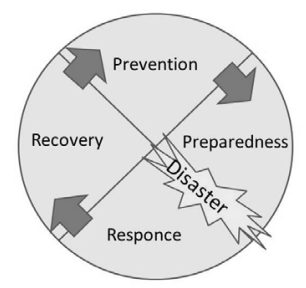

Figure 1: Emergency management cycle $[36,37]$.

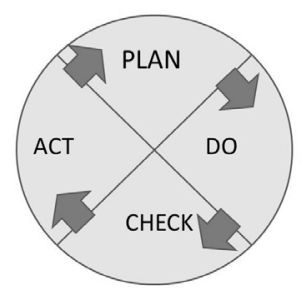

Figure 2: $\quad$ PDCA model [38, 39]. 
Curriculum development was motivated by the EU Commission and member states strategic framework "Education and Training 2020", which is why all lectures are planned in independent modules. From the beginning the master's level curriculum was designed for all Baltic Sea Region countries and therefore all the course materials were compiled, in addition to Estonian, also in English.

Curriculum methodology is based on Taba [43] instructions. Compliance to the instructions means actions according to the following scheme: explaining needs, posing objectives, compiling the content and constitution of the curriculum and working out the teaching methodology.

\subsection{Curriculum context and constitution}

The prerequisite for commencing studies on the Master's level is a Bachelor's level degree, professional higher education or an equivalent qualification and at least two years experience in the field of public defence. A student is obligated to choose subjects in the capacity of at least 25 ECTS from among the specialty related elective subjects provided in the curriculum. The curriculum is focused on different activity parts in cases of accidents.

The main idea of the curriculum is to manage the full cycle of the emergency management. Following, the authors give an overview of the curriculum through four main steps:

1) Prevention and mitigation as risk managing. The main points are to provide an understanding of the uniqueness of the flora and fauna in the Baltic Sea area as well as the possible impact in case of pollution with dangerous substances and possible accidents. The main objectives are:

a. Baltic Sea and living environment: To provide the students with an aim of the coastline and the beach of Estonia and to give an overview of the individual characteristics and peculiarities of the living environment in the Baltic Sea.

b. Dangerous goods and safety technique: To provide the students with knowledge of dangerous goods, which are transported at sea, their identification and neutralization. .

c. Maritime traffic in the Baltic Sea: To provide an overview of the main topics of the maritime traffic in Baltic Sea; possible polluters and their response.

2) Preparedness and detection as a necessary legislative base and technical equipment. The main points are focused on equipment and techniques for detecting, monitoring and acting. The objectives are:

a. Detecting pollutants and response authorities. International co-operation: To provide an overview of oil spill detection methods, response authorities and international co-operation in the area of the Baltic Sea. 
3) Response and action in case of accident

a. Oil spill response work at the sea: To provide an overview of the oil spill response activities and authorities responsible for response at sea.

b. Oil spill response works in coastal waters: To provide an overview of the oil spill response work and authorities in coastal waters.

4) Recovery, cleaning and investigation.

a. Practical shorelines clean up: To provide an overview of the oil spill response work and authorities on the coast.

b. Wildlife Response and Preparedness: To provide an overview of the wildlife rescue methods and techniques.

c. Investigation and criminal response for polluters: Rules of investigation, detention and arrest of vessels as well as composing maritime claims against ship owners and crew in cases of illegal dumping and pollution of the marine environment

\subsection{Teaching methodology and curriculum application}

Teaching will involve three main methods: theoretical, virtual simulation and practical training.

Theoretical studies involve the entire emergency management cycle in the context of accidental marine and coastal pollution. An important difference from short-time courses is the approach to give students a comprehensive background about the unique character of the Baltic Sea and its flora and fauna, as briefly referred in subdivision 3.1 of current paper. Other important topics, highlighted during the study, will be marine traffic arrangement and accidents, including accidents with dangerous goods, including oil products, observed in subdivision 3.2. Special attention is given to cooperative mechanisms for pollution management and control, mentioned in subdivision 3.3. The regulation and organization topics will be divided between different subjects of the curriculum. The theoretical module of the curriculum is mainly e learning. All the teaching materials are looked over, assessed and improved during the curriculum improvement process, considering the latest achievements of research and development in corresponding fields.

Virtual studies embrace the modeling of tanker accidents, oil spills and associated accidental pollution scenarios. These studies will be conducted on the basis of the virtual simulation tools of the Estonian Maritime Academy. The tools allow modeling tanker accidents in real weather conditions, defining exactly the dangerous goods and tanker coordinates. It is possible to model the scenario of a specific case and to see when and where the pollution may be offshore, on-shore or already at the shoreline. 
Practical training will be organized on the basis of Estonian Academy of Security Sciences (laboratory and field works concerning dangerous goods) and partially in cooperation and with the assistance of several organizations, for example: the Rescue Board (coastal water oil spill technique), Police and Border Guard (oil spill response at sea), Estonian Nature Fund (wildlife), Environmental Ministry (investigation and criminal response), etc.

The curriculum application process is planned in two phases: an experimental phase (further also: small cycle) and full-scale application phase (further also large cycle). Both phases are conducted, following the PDCA principles in specific context:

- $\quad$ PLAN - planning of the course(s),

- DO - curriculum implementation, including carrying out of the training;

- $\mathrm{CHECK}$ - analysis and assessment of the feedback information, concerning the achievements of the objectives and possible non-conformances to the planned actions;

- $\mathrm{ACT}$ - improvement and further development actions.

The PDCA approach in the current context could provide a good compatibility with the quality management of the Estonian Academy of Security Sciences and also predispose possible implementation in other states and schools. The cyclic design of the steps of the scheme is demonstrated in figure 3 .

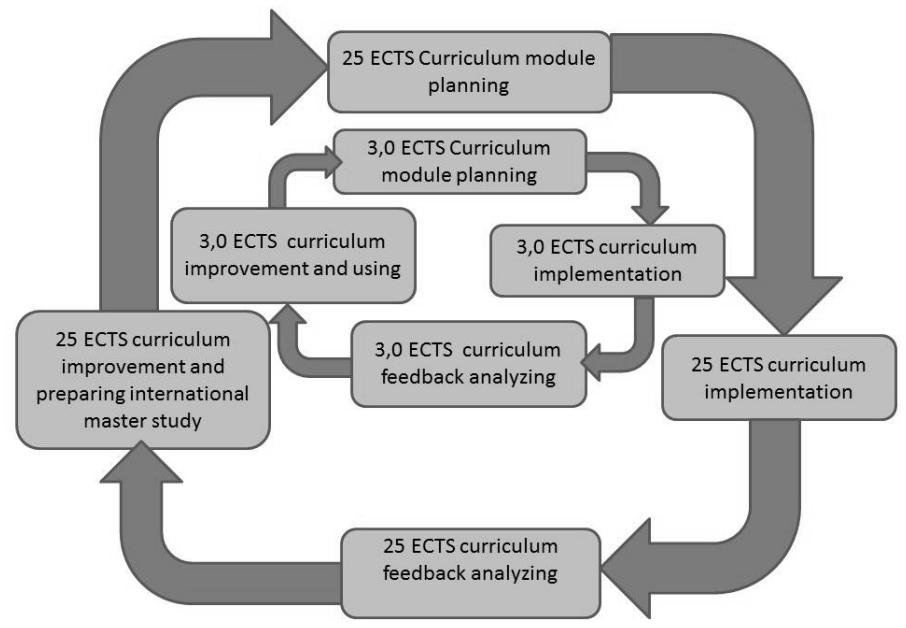

Figure 3: Curriculum application phases.

The experimental application phase (short-time course: 3 ECTS; small cycle) is intended to take place already in spring 2012 and the course is designed for the students of the Estonian Academy of Security Sciences and Estonian Maritime Academy as well as for the specialists of oil spill response from Estonian Rescue 
Board. The practical application phase (full-scale implementation: 25 ECTS; large cycle) will hopefully take place during the college year 2012-2013. Future direction in case of success is the attribution of an international dimension with the involvement of foreign students and possible training in cooperation with suitable schools or universities and other institutions from EnSaCo partner countries.

\section{Conclusion}

The development of a master's study level curriculum accomplished one of the essential goals of the EnSaCo Oil Spill project and established suppositions for the step-by step application. The application of the curriculum will be conducted in $2+1$ phases: experimental, practical and finally the international. The curriculum enables the training of highly qualified specialists, capable of applying their competence in the field of internal security and also as competent trainers in the field of oil pollution and response. The graduates, who have passed the full-scale training course, will be able to implement their extensive competence of marine and coastal pollution management into the specific context of the Baltic Sea environment and have good skills for working in an international cooperation framework.

\section{Acknowledgement}

European Social Fund's Doctoral Studies and Internationalization Program DoRa supported this research. The authors would like to thank the colleagues from $\mathrm{EnSaCo}$ project for rendered guidance and Tia Ruutopõld for linguistic advice and correction.

\section{References}

[1] Oil tanker spill statistics 2011. ITOPF, 2011.

[2] The Community framework for cooperation in the field of accidental or deliberate Marine Pollution.: Humanitarian Aid and Civil Protection, European Commission, http://ec.europa.eu/echo/civil_protection/ civil/marin/mp01 en introduction.htm

[3] Particularly Sensitive Sea Areas. IMO, http://www.imo.org/blast/ mainframe.asp?topic id $=1357$

[4] Helsinki Commission. Baltic Marine Environment Protection Commission, http://www.helcom.fi/

[5] Environment and Safety Management Cooperation on Shoreline Oil Spill Response. EnSaCo, http://www.ensaco.fi/pages/en/frontpage.php

[6] EnSaCo Oil Spill Approved Application Central Baltic INTERREG IVA Programme 2007-2013. 
[7] Gwin, P., Who's Still Spilling Oil in the Seas? National Geographic, Posted Apr 30, 2009, http://blogs.ngm.com/blog_central/2009/04/crude-currents.html

[8] Patin, S. and Casio, E., Accidents during the offshore oil and gas development, http://www.offshore-environment.com/accidents.html

[9] Hassler, B., Accidental Versus Operational Oil Spills from Shipping. Royal Swedish Academy of Sciences, 2011.

[10] Guano Island, http://guanoisland.wordpress.com/2007/02/12/mv-erika-oilpollution-trial/

[11] Response and remedation of the "Prestige" (lessons learned, Technical workshop on oil spills response and remedation, Turkmenbashy, 2008.

[12] Regulation (EC) No 417/2002 of the European Parliament and the Council, Official Journal of the European Communities, 2002.

[13] Garnacho, E., Law, R. J., Schallier, R. and Albaies, J., Targeting European R\&D for accidental marine pollution. Marine Policy, 34, pp. 1068-1075, 2010.

[14] Aguilera, F., Mendez, J., Pasaro, E., and Laffon, B., Review on the effects of expousure to spilled oils on human health. Journal of Applied Toxicology, 30, pp. 291-301, 2010.

[15] PetroStrategies, Inc. Oil Transportation, http://www.petrostrategies.org/ Learning_Center/oil transportation.htm\#WaterborneTransportation

[16] The Baltic Sea Action Plan. HELCOM, 2007.

[17] Ecosystem Health of the Baltic Sea 2003-2007. HELCOM Initial Holistic Assessment, Baltic Sea Environment Proceeding no 122, 2010.

[18] Ruskule, A., Kuris, M., Leipute, G., Vetemaa, M. and Zableckis, Š., See the Baltic Sea: unique assets we share. Baltic Environmental Forum Latvia, 2009.

[19] Background and analyses: EU Strategy for the Baltic Sea Region. Office for Official Publications of the European Union, Luxembourg, 2010.

[20] Fifth Baltic Sea Pollution Load Compilation (PLC-5). Helsinki Commission, Baltic Sea Environment Proceeding no 128, 2011.

[21] Ensuring safe shipping in the Baltic, Helsinki Commission (HELCOM), 2009.

[22] Report on shipping accidents in the Baltic Sea area during 2010. Helsinki Commission, 2010.

[23] Traffic and Navigation, HELCOM, http://www.helcom.fi/shipping/ navigation/en GB/navigation/

[24] Kujala, P., Hänninen, M., Arola, T. and Ylitalo, J., Analysise of the marine traffic safety in the Gulf of Finland. Reliability Engineering and System Safety, 94, pp. 1349-1357, 2009.

[25] Ihaksi,T., Kokkonen, T., Helle, I., Johna, A., Lecklin, T. and Kuikka, S., Combining Conservation Value, Vulnerability, and Effectiveness, Environmental Managment, 47, pp. 802-813, 2011.

[26] Larsson, U., Elmgren, R., and Wulff, F. Eutrophication of the Baltic Sea causes and consequences, Ambio 14, pp. 9-14, 1985. 
[27] Ęrtebjerg, G., Andersen, J.H. and Hansen, O.S. (eds.) Nutrients and Eutrophication in Danish Marine Waters. Ministry of the Environment, Danish Environmental Protection Agency and National Environmental Research Institute, 2003.

[28] Country Profiles. ITOPF, http://www.itopf.com/information-services/ country-profiles/

[29] Palopäällyston koulutusohjelma: opetussuunitelma [The Fire Officer's Training Programme: Curriculum], http://www.intermin.fi/pelastus/ images.nsf/files/0B00E767C40E4EC8C22575C200354FB0/\$file/amkN9\% 20ops.pdf

[30] Vapaaehtoiset öljyntorjuntajoukot [Volunteer oil spill response forces]. World Wide Fund for Nature Finland, http://wwf.fi/maapallomme/ itameri/merenkulun-turvallisuus-ja-oljyntorjunta/oljyntorjuntajoukot/

[31] Alusöljyvahingon rannikotorjunnan koulutussuunitelma. [Marine oil accident coastal combat training curriculum]. Kymenlaakso University of Applied Sciences, Kotka: Tammerprint, 2011.

[32] MSB - Swedish Civil Contingencies Agency, https://www.msb.se/

[33] Marine Environmental Protection Program (MEPP). Kalmar Maritime Academy, CMI Marine AB, http://www.cmimarine.se/mepp-training

[34] Oil Pollution Prevention and Response Training. Makarov Training Centre, http://www.makarov.spb.ru/eng/training/course_opr_eng.html

[35] Oil pollution: about the oil related training. Estonian Fund for Nature, http://www.elfond.ee/en/what-we-do/sea/oil-pollution/about-the-oil-relatedtraining

[36] Prevention. Humanitarian Aid and Civil Protection, European Commission, http://ec.europa.eu/echo/civil protection/civil/prevention overview.htm

[37] Schwab, A. J., Eschelbach, K. and D. J. Browner, Hazard mitigation and Preparedness, Wiley, 2007.

[38] ISO 9001:2008 Quality management systems. Requirements with guidance for use.

[39] ISO 14001:2004 Environmental management systems. Requirements with guidance for use.

[40] Kubo, T., Hisada, Y., Murakami, M., Kosuge, F. and Hamano, K, Application of an earthquake early warning system and a real-time strong motion monitoring system in emergency response in a high-rise building. Soil Dynamics and Earthquake Engineering, 31, pp. 231-239, 2011.

[41] Smith, K., Environmental Hazards: assesseing risk and reducing disaster. London and New York: Routledge, 2001.

[42] Kirby, M. F. and Law, R. J., Accidental spills at sea - Risk, impact, mitigation and the need for co-ordinated post-incident monitoring. Marine Pollution Bulletin 56, pp. 1243-1247, 2008.

[43] Taba, H., Curriculum Development: Theory and practice, New York: Harcourt Brace and World, 1962. 